\begin{tabular}{|l|l|l|l|}
\hline Natura Somogyiensis & $\mathbf{5}$ & $29-40$ & Kaposvár, 2003 \\
\hline
\end{tabular}

\title{
A Tetves-patak hidrozoológiai vizsgálata
}

\author{
PONYI JENŐ és P. ZÁNKAI NóRA
}

MTA Balatoni Limnológiai Kutatóintézete, H - 8237 Tihany, Pf. 35., Hungary

PONYI J., P. ZÁNKAI N.: The hydro-zoological examination of Tetves stream

Abstract: During the survey of the invertebrate fauna of the Tetves stream the authors found 63 taxons in the years 1999 and 2001, whose distribution according to bigger groups is as follows: Cladocera 8, Copepoda 14, Gastropoda 9, Hirudinea 5, Hydracarina 13, Malacostraca 4, Ostracoda 6, Tricladida 4. In the two examined years, significant changes took place in the specific composition of the animal groups, the reason of which could be the shortage of rainfalls in 2001 , the water quality change of the stream and the effect of the water flowing in the stream from the fish-ponds.

Key words: stream, Crustacea, water mites, meso-zoo fauna, macro-zoo fauna.

\section{Bevezetés}

A balatoni patakok gerinctelen állatvilágának kutatása az 1900-as évek első felére nyúlik vissza. Ekkor születtek az első adatok a tóba folyó patakok Astacus astacus és Synurellea ambulans rákjainak elöfordulásáról. Az akkori idők patak-kutatásának fontos állomását jelentette a puhatestüek (Mollusca) vizsgálata. 1932-ben és 1953-ban intenzív vizsgálatok indultak a víziatkák (Hydracarina) és a harangállatok (Peritricha) felmérése területén. (Bővebb adatok PoNYI 1997-es munkájában).

A Balatonba ömlő patakok szervezett kutatását Sebestyén Olga indította el az 1950-es évek első felében. A vizsgálatok a Pécsely és Aszófői patakokra terjedtek ki. Az állatvilágon belül részletesen vizsgálták a Protozoa, Rotatoria, Gastrotricha, Malacostraca és Hemiptera csoportokat (ENTZ et al., 1954; ENTZ 1958; KoHL 1957, LuKACsovics 1957.,1958). A kutatások különböző okok miatt hamar félbeszakadtak. Több évtizedes szünet után az 1990-es évek elején, az OTKA jóvoltából kezdődtek el ủjra a rendszeres patak-kutatások, melyek eredményei "A Balaton-felvidék fontosabb, a tóba ömlő patakjainak összehasonlító zoológiai vizsgálata (1994-1997)" címü jelentésben került összefoglalásra (OTKA ny.sz.: T 012788). E program keretében 6 patakban folytak vizsgálatok. Sajnos a támogatásra kapott összeg csak a legszükségesebb alaptájékozódásra volt elégséges. 1999-től a MeH támogatásával a Balaton déli oldalán befolyó patakok kutatását kezdtük el. E kutatásoknak két fő célja volt: (1) a gerinctelen fauna feltárása, megismerése, (2) zoomonitoring rendszer kiépítésével kapcsolatos kutatások. Jelen tanulmányban a vizsgált patakok közül csak a Tetves-patak zoológiai vizsgálatára és a kimutatott állatcsoportok ismertetésére térünk ki. 


\section{Anyag és módszer}

\section{A Tetves-patak általános jellemzése}

A patak vízgyüjtőjének mezőgazdaságára a haltenyésztés ( 8 irmapusztai halastó) és a földmüvelés a jellemzö. A vízfolyás hossza $24,7 \mathrm{fkm}$, a vízgyüjtő területe $79,0 \mathrm{~km}^{2}$, a középvízhozama $0,230 \mathrm{~m}^{3} / \mathrm{s}$. A kutatási időszakban a csapadék mennyisége nagymértékben befolyásolta a patak vízhozamát. A 2001-es vizsgálatok időszakában a csapadékmennyiségek jelentősen elmaradtak az 1999-es évitől. Ezt \%-ban kifejezve pl. májusban $66 \%$, júniusban $72 \%$ volt. A patak vízminősége az érvényben lévő szabvány (MSZ 12749:1993) szerint a III és II osztályba sorolható.

\section{Gyüjtőhelyek, állatok gyüjtése és vizsgálata}

Három vizsgálati területet választottunk, ezek Somogybabod (4.sz.gy.hely), Visz (5. sz.gy.h), Balatonszemes (6. sz.gy.h.) (1. ábra). A gyüjtőhelyek hagyományos számozástól való eltérése azzal magyarázható, hogy azonos időpontban egyszerre több patakot vizsgáltunk, így minden vizsgálati hely egy adott számot kapott, melyet most nem akartunk átszámozni a későbbi esetleges összehasonlítások miatt. A mintavételezések időpontjai a következök voltak: 1999. május 25., július 27., szeptember 5., 2001. május 23., július 23., szeptember 3 .

A gyüjtőhelyek botanikai szempontból következőképpen voltak jellemezhetőek:

4.sz.gy.hely: Tavasszal csak egy szárazföldi füféle volt az uralkodó, melyet nyáron és összel egy kevés Sium latifolium tett változatosabbá. A partszegélyen a füzfabokrok voltak a jellemzők.

5. sz.gy.hely: Mind a három évszakban a gyüjtési helyet sürün benőtte a Sium latifoliuım, mellette a Phragmites föleg a partszegélyen sürün, a Carex $s p$. pedig szórványosan volt megtalálható.

6. sz.gy.hely: Tavasszal az Elodea canadensis, Myriophyllum spicatum egyenlő arányban, a Ceratophyllum demersus pedig szórványosan fordult elö. Nyáron annyiban változott a kép, hogy a $C$. demersum között szigetszerüen elhelyezkedö Lemna minor és Spirodella polyrrhiza lépett fel. Összel a pangó vizet vastagon nötte be a Ceratophyllum demersum, közte néhány szál Elodea canadensis is zöldelt. A víz felszínének nagy részét Lemna minor borította. A partszegélyt végig lekaszált Carex sp. rothadt levelei takarták be.

A zoológiai mintákat az egyelőhálóval történő gyüjtési módszerrel (CHESTER 1980) nyertük. A begyüjtött minták egy részét a helyszínen rögzítettük. A formalin végkoncentrációja 5-10\%-os volt. A minták másik részét 25 literes müanyaghordókban a tihanyi laboratóriumba szállítottuk. Az élő minták víztérfogata 10-10 liter volt. Az anyagot külön-külön nagyméretü fotótálakba öntöttük. Az állatok kiválogatását ill. állatcsoportok szerinti elkülönítését szabad szemmel, ill. binokuláris mikroszkóp alatt végeztük. Egyes állatcsoportok kiválogatása csak az élő mintákból történt, ezek a következők: Tricladida, Hirudinea, Hydracarina.

A vizsgálatok a következő állatcsoportokra terjedtek ki: Tricladida, Hirudinea, Mollusca, Cladocera, Ostracoda, Copepoda, Malacostraca). 


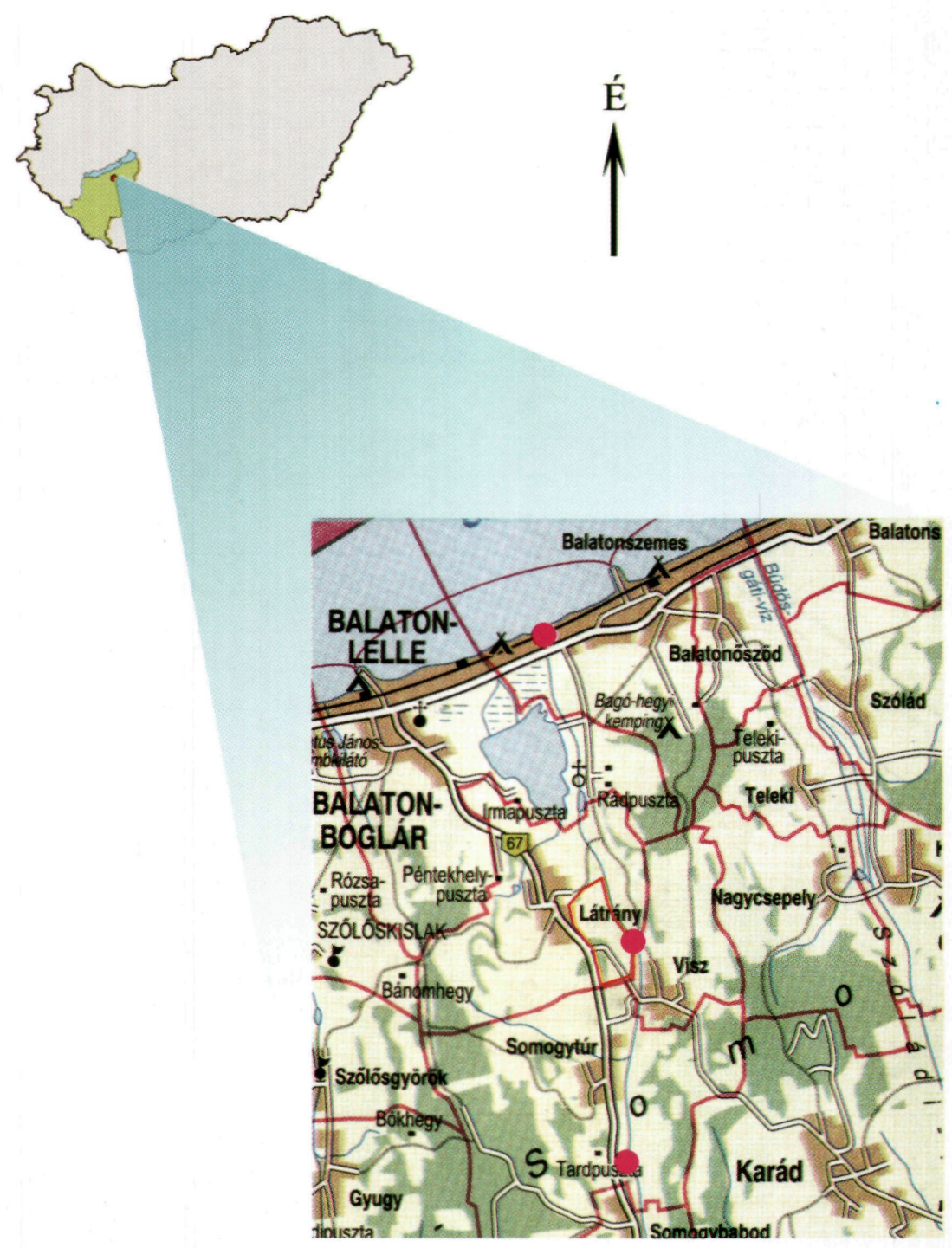

1. ábra: Gyújtési helyek a Tetves-patakon 
1. táblázat: Makrozoofaunát (Tricladida, Gastropoda, Hirudinea, Malacostraca) alkotó fajok előfordulása a Tetves-patakban 1999 és 2001 években

\begin{tabular}{|c|c|c|}
\hline Taxon & 1999 & 2001 \\
\hline \multicolumn{3}{|l|}{ Tricladida } \\
\hline Dendrocoelum lacteum (Müller) & $\mathrm{X}$ & $\mathrm{X}$ \\
\hline Dugesia gonopcephala (Dugés) & $\mathrm{X}$ & $\mathrm{X}$ \\
\hline Dugesia lugubris (Schmidt) & $\mathrm{X}$ & $\mathrm{X}$ \\
\hline Polycelis nigra (Müller) & $\mathrm{X}$ & $\mathrm{X}$ \\
\hline \multicolumn{3}{|l|}{ Gastropoda } \\
\hline Anisus spirorbis (L.) & $\mathrm{X}$ & \\
\hline Anisus vortex $\mathrm{L}$. & & $\mathrm{X}$ \\
\hline Anisus vorticulus Torschel & & $\mathrm{X}$ \\
\hline Bithynia leachi (Sheppard) & $\mathrm{X}$ & \\
\hline Bithynia tentaculata $\mathrm{L}$. & & $\mathrm{X}$ \\
\hline Lymnea $\mathrm{sp}$. & $\mathrm{X}$ & \\
\hline Planorbarius corneus $(\mathrm{L})$. & $\mathrm{X}$ & \\
\hline Planorbis carinatus Müller & & $\mathrm{X}$ \\
\hline Succinea elegans f. hungarica Hazay & & $\mathrm{X}$ \\
\hline \multicolumn{3}{|l|}{ Hirudinea } \\
\hline Erpopdella octoculata (L.) & $\mathrm{X}$ & $\mathrm{X}$ \\
\hline Glossiphonia complanata (L.) & & $\mathrm{X}$ \\
\hline Glossiphonia heteroclita (L.) & $\mathrm{X}$ & \\
\hline Hemiclepsis marginata (O.F.Müller) & $\mathrm{X}$ & $\mathrm{X}$ \\
\hline Piscicola geometra $(\mathrm{L})$. & $\mathrm{X}$ & $\mathrm{X}$ \\
\hline \multicolumn{3}{|l|}{ Malacostraca } \\
\hline Gammarus fossarum Koch & & $\mathrm{X}$ \\
\hline Gammarus roeseli Gervais & $\mathrm{X}$ & $\mathrm{X}$ \\
\hline Gammarus roeseli var. triacanthus Schaf. & & $\mathrm{X}$ \\
\hline Asellus aquaticus $\mathrm{L}$. & $\mathrm{X}$ & $\mathrm{X}$ \\
\hline Összesen: & 14 & 17 \\
\hline
\end{tabular}

Eredmények

\section{Makrozoofauna (Tricladida, Hirudinea, Mollusca, Malacostraca)}

A patakban mindkét vizsgálati évben 4 Tricladida fajt figyeltünk meg (1. táblázat). A gyüjtőhelyek közül mind a négy csak a Balaton közeli mintavételi helyen (6. sz. gy.h.) fordult elő (2. táblázat). A Polycelis nigra volt az egyetlen taxon, amelyik 1999-ben a középső, 2001-ben pedig a felső patakszakaszból is előkerült. Nyáron relatív magas egyedszámban gyüjtöttük a torkolat közeli lelőhelyen (13 és 28 e/minta). A vizsgálataink során 8 Mollusca taxont mutattunk ki (1. táblázat). Feltünő volt, hogy az 1999-ben kimutatott 4 faj helyett 2001-ben újabb, eddig nem megfigyelt taxont gyüjtöttünk, továbbá 1999-ben nyári mintákból hiányoztak a puhatestüek (2. táblázat). 2001-ben nyáron 3 fajt is megfigyeltünk, jelentős egyedszámban (12 e/minta) csak az Anisus vortex fordult elő. 
2. táblázat: Makrozoofauna (Tricladida, Planaria, Gastropoda, Hirudinea, Malacostraca) elöfordulása a Tetves-patak három gyüjtőhelyén 1999-2001 években

\begin{tabular}{|c|c|c|c|c|c|}
\hline Dátum & & 999 & & 200 & \\
\hline Mintavé teli hely & \begin{tabular}{|l|l|l}
4 & 5 \\
\end{tabular} & $5: 6$ & & 45 & 6 \\
\hline Tricladida & & & & & \\
\hline Dendrocoelum lacteum (Müller) & & 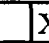 & & & $\mathrm{X}$ \\
\hline Dugesia gonocephala (Dugés) & & $I$ & & & $\mathrm{X}$ \\
\hline Dugesia lugubris (Schmidt) & & 2 & & & $\mathrm{X}$ \\
\hline Polycelis nigra (Müller) & & \begin{tabular}{l|l}
$\mathrm{X}$ & 2 \\
\end{tabular} & $x$ & & $\mathrm{X}$ \\
\hline Gastropoda & & & & & \\
\hline Anisus vorticulus Troschel & & & & & $\mathrm{X}$ \\
\hline Anisus spirorbis (L.) & & $\Sigma$ & & & \\
\hline Anisus vortex $\mathrm{L}$. & & & & & $\mathrm{X}$ \\
\hline Bithynia leachi (Sheppard) & & $\Sigma$ & & & \\
\hline Bithynia tentaculata $\mathrm{L}$. & & & & & $\mathrm{X}$ \\
\hline Lymnea $\mathrm{sp}$. & & $\mathrm{X}$ & & & \\
\hline Planorbarius carinatus Müller & & & & & $\mathrm{X}$ \\
\hline Planorbis corneus (L.) & & I & & & \\
\hline Succinea elegans f. hungaricus Hazay & & & & & $\mathrm{X}$ \\
\hline Hirudinea & & & & & \\
\hline Erpopdella octoculata (L.) & $\mathrm{X} \mid \mathrm{z}$ & $\mathrm{X} \mid \mathrm{I}$ & & & $\mathrm{X}$ \\
\hline Glossiphonia complanata (L.) & & & & & $\mathrm{X}$ \\
\hline Glossiphonia heteroclita (L.) & $\mathrm{X}$ & & & & \\
\hline Hemiclepsis marginata (O.F.Müller) & & 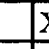 & & & $\mathrm{X}$ \\
\hline Piscicola geometra (L.) & & \begin{tabular}{c|c} 
\\
$x$
\end{tabular} & & & $\bar{x}$ \\
\hline Malacostraca & & & & & \\
\hline Gammarus fossarum Koch & & & $\mathrm{X}$ & \begin{tabular}{l|l}
$\mathrm{X}$ & $\mathrm{x}$ \\
\end{tabular} & \\
\hline Gammarus roeseli Gervais & $\mathrm{x}$ & $\mathrm{X}$ & $\mathrm{x}$ & \begin{tabular}{|l|l}
$\mathrm{x}$ & $\mathrm{x}$ \\
\end{tabular} & \\
\hline Gammarus roeseli var. triacanthus Schaf. & & & & $\begin{array}{ll}\mathrm{x} & \mathrm{x} \\
\end{array}$ & \\
\hline Asellus aquaticus L. & & & & & \\
\hline
\end{tabular}

3. táblázat:A Tetves-patak víziatka faj- és egyedszámának évszakos változása 1999-ben

\begin{tabular}{|c|c|c|c|c|c|c|c|c|c|}
\hline Gyûjtési idõ & \multicolumn{3}{|c|}{ május 25.} & \multicolumn{3}{|c|}{ július 27.} & \multicolumn{3}{|c|}{ szeptember 5 . } \\
\hline Mintavétel helye & 4 & 5 & 6 & 4 & 5 & 6 & 4 & 5 & 6 \\
\hline Arrenurus globator & & & 3 & & & & & & 2 \\
\hline Arrenurus sp. & & & & & & & & & 1 \\
\hline Hydrachna globosa & & & 3 & & & 3 & & & 1 \\
\hline Limnesia fulgida & & & 4 & & & 13 & & & 1 \\
\hline Limnesia ny. & & & & & & 3 & & & \\
\hline Piona alpicola var. controversiosa & & & 1 & & & & & & \\
\hline Piona obturbans & & & 1 & & & & & & \\
\hline Piona pusilla & & & 1 & & & & & & \\
\hline Piona ny. & & & & & & 1 & & & \\
\hline Taxonszám: & \multicolumn{3}{|c|}{6} & \multicolumn{3}{|c|}{3} & \multicolumn{3}{|c|}{4} \\
\hline
\end{tabular}


A kétéves vizsgálatok során a patakból 5 Hirudinea fajt gyüjtöttünk be (1. táblázat), közülük 3 mindkét évben előfordult. A Glossiphonia heteroclita 1999-ben, a Glossiphonia complanata 2001-ben került hálóba. A két vizsgálati évben a fajok elöfordulása a patak 3 gyüjtőhelyén jelentős különbséget mutatott (2. táblázat). 2001-ben csak a tóba való beömlés előtti szakaszon fordultak elő pióca fajok, míg a korábbi vizsgálati évben a felső és középső patak szakaszokon 2-2 faj volt kimutatható. Egyedszám tekintetében az Erpobdella octoculata volt a leggyakoribb, egyes helyeken $15 \mathrm{e} / \mathrm{minta}$ is begyüjtésre került.

A Malacostraca osztályt 1999-ben a Gammarus roeseli képviselte (2. táblázat). Tavasszal a felső és középső vízterületen egyedszámuk magas volt (11-46 e/minta), nyáron számuk ugyanazon helyen valamelyest csökkent (1-40 e/minta). Összel a középső szakaszról eltüntek, mialatt a felső szakaszon a mintában még 40 egyed volt megfigyelhető. Az alsó szakaszokon az egész vizsgálati periódusban nem találtunk egyetlen példányt sem. 2001-ben a Gammaridae családot már 3 taxon képviselte. A korábbi vizsgálati évekhez hasonlóan a tóközeli partszakaszon egyetlen évszakban sem lehetett példányukat megfigyelni, feltehetően a nagyfokú szennyezettség (peszticid?) miatt. A felső és középső partszakaszon a 3 taxon \%-os összetétele gyüjtőhelyenként és évszakonként jelentősen eltért egymástól. Pl. a középső szakaszon \%-ban kifejezve a következő változások voltak megfigyelhetö:

$\begin{array}{lccc} & \text { tavasz } & \text { nyár } & \text { ősz } \\ \text { Gammarus fossarum } & 33 & 35 & 3 \\ \text { Gammarus roeseli } & 5 & - & 3 \\ \text { Gammarus roeseli var. triachantus } & 62 & 65 & 94\end{array}$

Az Asellus aquaticus fajt 1999-ben nem tudtuk gyüjteni, 2001-ben tavasszal és nyáron csak a tóközeli vizsgálati ponton volt jelen (6-11 e/minta).

A makrozoofauna összetételében két év alatt jelentős változás következett be, különösen feltűnő volt ez a Gastropoda-k esetében (1. táblázat). A Gammarus taxonok és az Asellus aquaticus hiánya a Tetves-patak egyes szakaszain 1999-ben, nagyfokú szennyezésre utal (2. táblázat). Ugyanakkor a Gammarus-ok megjelenése a felső és középfolyású szakaszokon a vízterületek tisztulását jelzi.

\section{Mezozoofauna}

\section{Viziatkák(Hydracarina)}

1999-ben a Tetves-patak felső folyású és középső folyású gyüjtőhelyein egyetlen évszakban sem találtunk víziatkákat, csupán a torkolat közelében voltak példányok. Összesen 6 taxont gyüjtöttünk, tavasszal, májusban a legtöbbet, míg nyáron csupán 3, ősszel 4 taxon került hálóba (3. táblázat). Az állományok évszakonként különböztek, a tavasziak és ösziek $43 \%$-ban, míg a tavasziak és a nyáriak csak $25 \%$-ban, a nyáriak és ősziek pedig $33 \%$-ban hasonlítottak egymásra. Az összes példányszám 38-nak adódott, tavaszszal és ősszel a fajok között kiegyenlitett volt a sürüség, nyáron egy taxon elszaporodása miatt a kis fajszámhoz nagyobb egyedszám tartozott.

Tavasszal és nyáron az állományokban a nőstények és petés nőstények voltak többségben

$(92 \%, 56 \%)$, ősszel a hímek aránya nőtt meg (60\%). Mind a tavaszi, mind az őszi állományokból hiányoztak a fiatal egyedek (nympha-k). Ennek feltehető oka, hogy a hüvős időjárás miatt a szokásosnál később keltek ki a lárvák, ill. nympha-vá alakulásuk és a vízbe visszajutásuk későbbi időre tolódott.

A torkolat közelében gyüjtött állományokban mint ez várható volt egyetlen "igazi pataki" víziatkát sem találtunk, az együttesek állóvízi, tavi, jellegzetesen olyan balatoni 
taxonokból álltak, melyek a tó déli partján élő víziatka populáció uralkodó fajai (pl. Arrenurus globator, Limnesia fulgida).

2001-ben a Tetves-patak víziatka állományát ismételten megvizsgáltuk a korábbiakkal azonos helyeken és közel azonos időpontokban. A felső folyású helyen ekkor sem találtunk víziatkákat, a középső partszakasz viszont benépesült ( 6 taxon), míg a torkolati részen csak tavasszal ( 1 taxon) és nyáron ( 2 taxon) voltak példányok. Összesen 8 taxont találtunk, hármat-hármat tavasszal és ősszel, ötöt nyáron (4. táblázat). Évszakosan az állományok 2001-ben még inkább különböztek egymástól, mint 2 évvel korábban, pl. a tavaszi és nyári együttesben egyetlen közös faj sem volt. Összesen 33 példányt tudtunk gyüjteni, közülük a torkolati részen csak 8 került hálóba.

Fiatal egyedek minden évszakban voltak a populációkban, tavasszal az állomány egyenlő arányban állt hím, nőstény és nympha példányokból, nyáron és ősszel a 20-22\%nyi fiatal mellett 50-63\%-ban voltak a hímek.

A Tetves-patak középfolyású szakaszán síkvidéki, áramló vizekre jellemző taxonokat (Atractides, Lebertia, Sperchon) találtunk, míg a torkolat közelében kizárólag állóvízi, tavi, balatoni fajok (Arrenurus, Hydrachna) kerültek hálóba (4. táblázat). A pataki taxonok küzöl az Atractides fluviatilis új hazai faj, melyet SzALAY (1964) A. nodipalpis var. fluviatilis-ként említ a környező országokból (Szlovákia, Jugoszlávia), ahol lassan folyó árkokban, gyorsfolyású patakokban, folyókban említik. Az Atractides distans csak 1972ben lett a magyar fauna tagja, amikor a Balaton északi partján betorkolló Egervíz-patakban megtaláltuk. Az Atractides ovalis elsősorban állóvízi faj, ritkán azonban folyók vizében is előfordul (SZALAY 1964), a Balatonban parti kövek alatt találtuk (ZÁNKAI 1993). A Sperchon clupeifer öszi elszaporódása ökológiai igényével magyarázható, a hüvösebb vizü patakokat kedveli.

\section{Kisrákok (Cladocera, Ostracoda, Copepoda)}

A vizsgálatok során 28 kisrák taxont mutattunk ki: 8 Cladocera, 6 Ostracoda, 14 Copepoda (5. táblázat). A két vizsgálati évben a fajok száma eltérő volt, a következők szerint:

\begin{tabular}{|c|c|c|}
\hline & 1999 & 2001 \\
\hline Cladocera & 7 & 5 \\
\hline Ostracada & 5 & 3 \\
\hline Copepoda & 11 & 10 \\
\hline Összes taxonszám: & 23 & 18 \\
\hline
\end{tabular}

4. táblázat: A Tetves patak víziatkái faj- és egyedszámának évszakos vảltozása 2001-ben

\begin{tabular}{|l|c|c|c|c|c|c|c|c|c|c|}
\hline Gyûjtési idó & \multicolumn{3}{|c|}{ május $\mathbf{1 4}$. } & \multicolumn{3}{|c|}{ július 23.} & \multicolumn{3}{|c|}{ szepte mber 3. } \\
\hline Mintavétel helye & $\mathbf{4}$ & $\mathbf{5}$ & $\mathbf{6}$ & $\mathbf{4}$ & $\mathbf{5}$ & $\mathbf{6}$ & $\mathbf{4}$ & $\mathbf{5}$ & $\mathbf{6}$ \\
\hline Arrenurus globator & & & & & & 2 & & & \\
\hline Arrenurus ny. & & & & & & 1 & & & \\
\hline Atractides distans & & & & & 1 & & & 1 & \\
\hline Atractides fluviatilis & & 4 & & & & & & & \\
\hline Atractides ovalis & & 4 & & & & & & & \\
\hline Hydrachna globosa & & & & & & 1 & & & \\
\hline Hydrachna ny. & & & 4 & & & & & & \\
\hline Lebertia ny. & & & & & & & & 2 & \\
\hline Sperchon papillosus compactilis & & & & & 3 & & & & \\
\hline Sperchon clupeifer & & & & & 1 & & & 8 & \\
\hline Sperchon ny. & & & & & 1 & & & & \\
\hline Taxonszám: & & 3 & & & 5 & & & 3 & \\
\hline
\end{tabular}


5. táblázat: Kisrák taxonok előfordulása a Tetves-patak három gyűjtőhelyén 1999 és 2001 években, a teljes vizsgálati időszakban

\begin{tabular}{|c|c|c|c|c|c|c|}
\hline Dátum m & & 1995 & & & 200 & \\
\hline Mintavételi hely & 4 & 5 & 6 & 4 & 5 & 6 \\
\hline Acanthocyclops robustus (Sars) & & $\mathrm{X}$ & $\mathrm{x}$ & & $\mathrm{X}$ & \\
\hline Alona rectangula Sars & & & $\mathrm{X}$ & & & \\
\hline Attheyella (Attheyella) crassa (Sars) & & $X$ & $\mathrm{X}$ & & & \\
\hline Attheyella trispinosa (Brady) & & & & & & $\mathrm{X}$ \\
\hline Candona sp. & $\mathrm{X}$ & $\mathrm{X}$ & $\mathrm{X}$ & & $\mathrm{X}$ & \\
\hline Ceriodaphnia reticulata (Jurine) & & & & & & $\mathrm{X}$ \\
\hline Chydorus sphaericus (O.F.Müller) & & & $\mathrm{X}$ & $\mathrm{X}$ & & $\bar{X}$ \\
\hline Cyclocypris laevis (O.F.Müller) & $\mathrm{X}$ & & & & & \\
\hline Cyclocypris ovum (Jurine) & & $\mathrm{X}$ & $\mathrm{X}$ & & & \\
\hline Cryptocyclops bicolor (Sars) & & & & & & $\mathrm{X}$ \\
\hline Cypria ophthalmica (Jurine) & & & & & & $\mathrm{X}$ \\
\hline Ectocyclops phaleratus (Koch) & & $\mathrm{X}$ & & & & \\
\hline Eucyclops serrulatus (Fischer) & $\mathrm{X}$ & $\mathrm{X}$ & $\mathrm{X}$ & $\mathrm{X}$ & & $\mathrm{X}$ \\
\hline Eucyclops serrulatus var. speratus (Lilljeborg) & & & $\mathrm{X}$ & $\mathrm{X}$ & $\mathrm{X}$ & \\
\hline Eucypris sp. & $\mathbf{X}$ & & & & & \\
\hline Iliocryptus agilis Kurz & $\mathrm{X}$ & & & & & \\
\hline Iliocryptus bradyi Sars & $\mathrm{X}$ & $\mathrm{X}$ & & $\mathrm{X}$ & & \\
\hline Leydigia leydigi (Schoedler) & & $\mathrm{X}$ & & $\mathrm{X}$ & & \\
\hline Macrocyclops albidus (Jurine) & & $\mathrm{X}$ & $\mathrm{X}$ & & & $\mathrm{X}$ \\
\hline Macrocyclops distinctus (Richard) & & & & & & $\mathrm{X}$ \\
\hline Megacyclops viridis (Jurine) & $\mathrm{X}$ & $\mathrm{X}$ & $\mathrm{X}$ & & & \\
\hline Mesocyclops leuckarti (Claus) & $\mathrm{X}$ & & & & & \\
\hline Paracyclops affinis (Sars) & $\mathrm{X}$ & $X$ & $X$ & & $\mathrm{X}$ & $\mathrm{X}$ \\
\hline Paracyclops fimbriatus (Fischer) & $\mathrm{X}$ & $\mathrm{X}$ & $\mathrm{X}$ & $\mathrm{x}$ & & \\
\hline Paracyclops poppei (Rehberg) & $\mathrm{X}$ & & & $\mathrm{X}$ & & \\
\hline Pleuroxus aduncus (Jurine) & $\mathrm{X}$ & & $\mathrm{X}$ & & & $\mathrm{X}$ \\
\hline Sida crystallina (O.F.Müller) & & $\underline{X}$ & & & & \\
\hline Simocephalus vetulus (O.F.Müller) & $\mathrm{X}$ & $\mathrm{X}$ & $\mathrm{X}$ & & & $\mathrm{X}$ \\
\hline Taxonszám: & 13 & 14 & 14 & & & 11 \\
\hline
\end{tabular}

Míg 1999-ben az összes kisrákok fajszáma mindhárom gyüjtőhelyen gyakorlatilag megegyezett, addig 2001-ben már jelentős különbségeket állapíthattunk meg (5. táblázat). A két vizsgálati év tavaszi időszakában a fajok száma jelenősen eltért egymástól (6. táblázat), 1999-ben 13, 2001-ben csak 4 fajt találtunk.

A kisrákok dominancia viszonyai is különböztek a két évben. 1999-ben egy eset kivételével a Cyclops-ok (7. táblázat), 2001-ben 3 esetben is egy Cladocera faj (Simocephalus vetulus) volt az uralkodó.

$\mathrm{Az}$ irmapusztai 8 halastó vizének a befogadója a Tetves-patak. Ennek hatása megmutatkozik a patak kisrákjainak összetételében is. Itt jegyezzük meg, hogy a halastavi rendszerek, a hiedelmekkel ellentétben, nem tisztítják a vizet. A szakirodalom már régóta használja a "halak okozta eutrofizáció" fogalmát. 
6. táblázat: Kisrák taxonok előfordulása a Tetves-patak három gyüjtőhelyén 1999 és 2001 években különböző évszakokban

\begin{tabular}{|c|c|c|c|c|c|c|c|c|c|c|c|c|c|c|c|c|c|c|}
\hline \multirow[t]{3}{*}{ Taxon } & \multicolumn{6}{|c|}{ május } & \multicolumn{6}{|c|}{ július } & \multicolumn{6}{|c|}{ szeptember } \\
\hline & \multicolumn{3}{|c|}{1999} & \multicolumn{3}{|c|}{2001} & \multicolumn{3}{|c|}{1999} & \multicolumn{3}{|c|}{2001} & \multicolumn{3}{|c|}{1999} & \multicolumn{3}{|c|}{2001} \\
\hline & 4 & 5 & 6 & 4 & 5 & 6 & 4 & 5 & 6 & 4 & 5 & 6 & 4 & 5 & 6 & \begin{tabular}{|l|}
4 \\
\end{tabular} & 5 & 6 \\
\hline Acanthocyclops robustus & & & $\mathrm{x}$ & & & & & & $\mathrm{X}$ & & $\mathrm{X}$ & & & $\mathrm{X}$ & $\mathrm{X}$ & & & \\
\hline Alona rectangula & & & $\mathrm{X}$ & & & & & & & & & & & & & & & \\
\hline Attheyella crassa & & & & & & & & & & & & & & $\mathbf{x}$ & $\mathbf{X}$ & & & \\
\hline Attheyella trispinosa & & & & & & & & & & & & $\mathrm{x}$ & & & & & & \\
\hline Candona sp. & $\mathrm{x}$ & $\mathrm{x}$ & $\mathrm{x}$ & & & & $\mathrm{X}$ & $\mathrm{X}$ & & & & & $\mathrm{X}$ & & & & $\mathrm{X}$ & \\
\hline Ceroidaphnia reticulata & & & & & & & & & & & & & & & & & & $\mathrm{X}$ \\
\hline Chydorus sphaericus & & & $\mathrm{x}$ & & & $\mathrm{X}$ & & & & & & & & & & $\mathrm{x}$ & & \\
\hline Cryptocyclops bicolor & & & & & & & & & & & & $\mathrm{X}$ & & & & & & $\bar{X}$ \\
\hline Cyclocypris laevis & & & & & & & & & & & & & $\mathrm{X}$ & & & & & \\
\hline Cyclocypris ovum & & $\mathrm{X}$ & $\mathrm{X}$ & & & & & & $\mathrm{X}$ & & & & & & & & & \\
\hline Cypria ophtalmica & & & & & & & & & & & & & & & & & & $\mathrm{X}$ \\
\hline Ectocyclops phaleratus & & & & & & & & & & & & & & $\mathrm{x}$ & & & & \\
\hline Eucyclops serrulatus & & $\mathrm{X}$ & $\mathrm{X}$ & & & & $\mathrm{X}$ & $\mathrm{X}$ & $\mathrm{X}$ & & & $\mathrm{X}$ & & $\mathrm{X}$ & $\mathrm{X}$ & $\mathrm{X}$ & & $\mathrm{X}$ \\
\hline Eucyclops serrulatus var. speratus & & & & & & & & & $\mathrm{X}$ & & & & & & $\mathrm{X}$ & $\mathrm{x}$ & $\mathrm{X}$ & \\
\hline Eucypris sp. & & & & & & & & & & & & & $\mathrm{x}$ & & & & & \\
\hline Iliocryptus agilis & & & & & & & & & & & & & $\mathrm{X}$ & & & & & \\
\hline Iliocypris bradyi & $\mathrm{X}$ & $\mathrm{x}$ & & & & & & & & & & & & $\mathrm{X}$ & & $\mathrm{x}$ & & \\
\hline Leydigia leydigi & $\mathrm{X}$ & & & $\mathrm{X}$ & & & & & & & & & & & & $\mathrm{X}$ & & \\
\hline Macrocyclops distinctus & & & & & & & & & & & & $\mathrm{X}$ & & & & & & \\
\hline Megacyclops viridis & $\mathrm{X}$ & $\mathrm{x}$ & & & & & & & $\mathrm{X}$ & & & & $\mathrm{x}$ & & $\mathrm{X}$ & & & \\
\hline Mesocyclops leuckarti & & & & & & & $\mathrm{x}$ & & & & & & & & & & & \\
\hline Paracyclops affinis & $\mathrm{X}$ & $\mathrm{x}$ & & & & & & $\mathrm{X}$ & $\mathrm{X}$ & & & $\mathrm{X}$ & & $\mathrm{X}$ & $\mathrm{X}$ & & $\mathrm{X}$ & $\mathrm{X}$ \\
\hline Paracyclops fimbriatus & $\mathrm{X}$ & $\mathrm{X}$ & $\mathrm{X}$ & & & & & $\mathrm{X}$ & & $\mathrm{X}$ & & & $\mathrm{X}$ & $\mathrm{x}$ & $\mathrm{X}$ & $\mathrm{x}$ & & \\
\hline Paracyclops poppei & & & & & & & $\mathbf{X}$ & & & $\mathrm{X}$ & & & & & & & & \\
\hline Pleuroxus aduncus & & & & & & $\mathrm{X}$ & & & & & & & $\mathrm{x}$ & & $\mathrm{X}$ & & & \\
\hline Sida crystallina & & & & & & & & & & & & & & $\mathrm{x}$ & & & & \\
\hline Simocephalus vetulus & & $\mathrm{X}$ & $\mathrm{X}$ & & & $\mathrm{X}$ & $\mathrm{X}$ & & & & & $\mathrm{X}$ & $\mathrm{X}$ & $\mathrm{x}$ & $\mathrm{X}$ & & & $\mathrm{X}$ \\
\hline Taxonszám: & 6 & 9 & 9 & 1 & - & 3 & 5 & 5 & 7 & 2 & 1 & 7 & 8 & \begin{tabular}{|l|l}
9 \\
\end{tabular} & 10 & \begin{tabular}{|l|l|}
6 \\
\end{tabular} & 3 & 7 \\
\hline
\end{tabular}

\section{Összefoglalás}

A szerzők a Balaton D-i partján befolyó Tetves-patak zoológiai vizsgálatát végezték 1999 és 2001 évek 3-3 évszakában. A kutatásaink célja a gerinctelen fauna egy részének feltárása volt, valamint újabb információk szolgáltatása a zoomonitoring rendszer kialakításához. A vizsgálatok során 63 taxont mutattak ki, melynek megoszlása nagyobb állatcsoportok szerint $\mathrm{ABC}$ sorrendben a következő: Cladocera 8, Copepoda 14, Gastropoda 9, Hirudinea 5, Hydracarina 13, Malacostraca 4, Ostracoda 6, Tricladida 4.

A makrozoofauna egyes csoportjainak (Gastropoda, Hirudinea, Malacostraca) faji 
7. táblázat: Kisrákok dominancia viszonyai a Tetves-patakban 1999 három évszakában

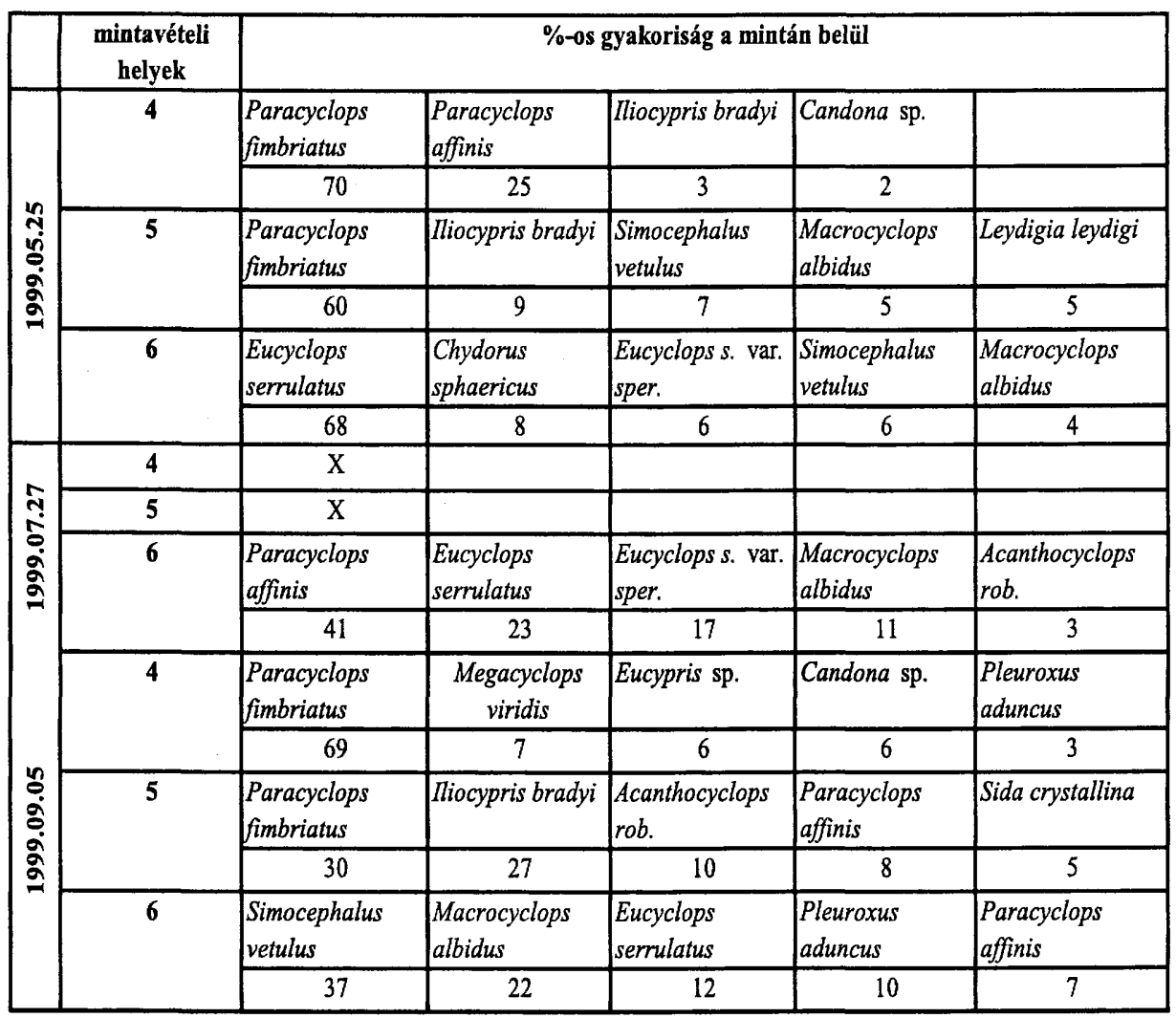

összetétele és szétterjedése a patak hosszában jelentősen különbözött a két vizsgálati évben. A jelenség magyarázatául szolgálhatnak a 2001 évi csapadékhiány mellett a patakot ért különböző szennyeződések.

A mezozoofauna tagjai is jelentősen különböztek a két vizsgálati évben. Így pl. míg 1999-ben a Tetves-pataknak nem volt önálló víziatka együttese, csupán a Balaton parti régióból a torkolatba sodródott taxonok példányai voltak gyüjthetők, addig 2001-ben a patak középső részein már igazi síkvidéki patakokra jellemző víziatka állomány alakult ki.

A kisrákok (Cladocera, Ostracoda, Copepoda) taxonszáma a korábbi évbe megfigyelt 23-ról 2001-ben 18-ra csökkent. A két év közötti fajszámbeli különbség különösen nagy volt a tavaszi időszakban, amikor is az 1999-ben kimutatott 13 faj 2001-ben 4-re csökkent.

2001-ben a kisrákok dominancia viszonyai is jelentösen megváltoztak, az 1999-es Cyclops dominanciát egy részleges Simocephalus (Cladocera) dominancia váltotta fel. A Tetves-patak állategyütteseiben bekövetkezett változásoknak több oka is lehetett: (1) 2001-ben bekövetkezett csapadékhiány, (2) a patak vízminőségének változása, (3) az irmapusztai 8 halastó vizének hatása. 
8. táblázat: Kisrákok dominancia viszonyai a Tetves-patakban, 2001 három évszakában

\begin{tabular}{|c|c|c|c|c|c|c|}
\hline & mintavételi & & \%-os gy: & akoriság a min & tán belül & \\
\hline & 4 & $\mathrm{i}$ & & & & \\
\hline$\frac{7}{n}$ & 5 & $\mathrm{i}$ & & & & \\
\hline : & 6 & \begin{tabular}{|l}
$\begin{array}{l}\text { Simocephalus } \\
\text { vetulus }\end{array}$ \\
\end{tabular} & $\begin{array}{l}\text { Chydorus } \\
\text { sphaericus }\end{array}$ & & & \\
\hline & & 75 & 25 & & & \\
\hline & 4 & $\begin{array}{l}\text { Paracyclops } \\
\text { fimbriatus }\end{array}$ & $\begin{array}{l}\text { Paracyclops } \\
\text { poppei }\end{array}$ & $\begin{array}{l}\text { Paracyclops } \\
\text { sp. }\end{array}$ & & \\
\hline$\stackrel{n}{2}$ & & 60 & 20 & 20 & & \\
\hline 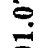 & 5 & $\bullet$ & & & & \\
\hline$\underset{\sim}{\stackrel{\sim}{~}}$ & 6 & \begin{tabular}{|l} 
Simocephalus \\
vetulus
\end{tabular} & $\begin{array}{l}\text { Attheyella } \\
\text { trispinosa }\end{array}$ & \begin{tabular}{|l|} 
Macrocyclops \\
albidus
\end{tabular} & $\begin{array}{l}\text { Eucyclops } \\
\text { serrulatus }\end{array}$ & $\begin{array}{l}\text { Cryptocyclops } \\
\text { bicolor }\end{array}$ \\
\hline & & 25 & 22 & 20 & 19 & 4 \\
\hline & 4 & $\begin{array}{l}\text { Paracyclops } \\
\text { fimbriatus }\end{array}$ & \begin{tabular}{|l} 
Eucyclops \\
serrulatus
\end{tabular} & \begin{tabular}{|l} 
Eucyclops ser. \\
v. sper.
\end{tabular} & $\begin{array}{l}\text { Chydorus } \\
\text { sphaericus }\end{array}$ & \begin{tabular}{|l}
$\begin{array}{l}\text { Iliocypris } \\
\text { bradyi }\end{array}$ \\
\end{tabular} \\
\hline$\overbrace{0}^{m}$ & & 40 & 27 & 13 & 7 & 6 \\
\hline . & 5 & - & & & & \\
\hline Д̊ & 6 & \begin{tabular}{|l}
$\begin{array}{l}\text { Simocephalus } \\
\text { vetulus }\end{array}$ \\
\end{tabular} & \begin{tabular}{|l|} 
Eucyclops \\
serrulatus
\end{tabular} & \begin{tabular}{|l} 
Macrocyclops \\
albidus
\end{tabular} & \begin{tabular}{|l}
$\begin{array}{l}\text { Paracyclops } \\
\text { affinis }\end{array}$ \\
\end{tabular} & $\begin{array}{l}\text { Ceriodaphnia } \\
\text { reticulata }\end{array}$ \\
\hline & & 30 & 22 & 19 & 11 & 11 \\
\hline
\end{tabular}

\section{Köszönetnyilvánítás}

A kutatásokat a MeH támogatta, Kóbor István kémiai, Kravinszkaja Gabriella a hidrológiai és hidrometerológiai adatokat bocsájtotta rendelkezésünkre. A zoológiai anyag gyüjtésében Nyári Gusztáv volt segítségünkre, a zoológiai anyag válogatását S. Mecsnóbel Ildikó végezte.

\section{Irodalom}

Chester, R. K. (1980): Biological Monitoring Working Parry. National Testing. - Technical Memorandum No. 19. DOE/WDU.

Entz B., Kohl E., Sebestyén O., Stiller J., Tamás G., VARga L. (1954): A Balatonba ömlő vizek fiziológiai és biológiai vizsgálata I. A Pécsely-patak. - Annal. Biol. Tihany, 22, 61-183.

ENTZ, B. (1958): Az Aszófői Séd továbbá a Pécsely-patak és az Aszóföi Séd torkolata közt a Balatonba ömlő patakok hőmérsékleti és vízkémiai viszonyai. - A patakok elsődleges termeléséről. - Annal. Biol. Tihany, 25, 109-136.

KoHL E. (1957): Az Aszóföi Séd mikrovegetációja I. Algák (Kovamoszatok kivételével). - Annal. Biol. Tihany, 24, 103-130.

Lukacsovics F. (1957): Az Aszófői Séd vízi és vízfelszíni Hemipterái. - Annal. Biol. Tihany, 24, $131-132$.

Lukacsovics F. (1958): Az Aszófői Séd Malacostraca fajainak elterjedése és ökológiai vizsgálata. - Annal. Biol. Tihany, 25, 165-172.

PONYl J. (1997): A Balaton-felvidék patakjainak zoológiai vizsgálata. - Hidrol. Tájékoztató, október, 18-22.

P. ZÁNKAI N. (1993): A Balaton északi partjának víziatkái. - Állatt. Közlem., 79, 113-134.

SzALAY L. (1964): Víziatkák-Hydracarina. - Akad. Kiadó, Budapest, Fauna Hung. 72, 1-380 + 1-7. 


\section{The hydro-zoological examination of Tetves stream}

JENő PONYI \& NóRa P. ZÁnKaI

The authors carried out surveys of the Tetves stream flowing in Lake Balaton at the southern shore in 3 seasons of the years 1999 and 2001. The purpose of the research was to reveal some part of the invertebrate fauna, as well as to provide further information for the establishment of the zoo-monotoring system. During the surveys 63 taxons were found, whose distribution according to bigger animal groups in alphabetical order is as follows: Cladocera 8, Copepoda 14, Gastropoda 9, Hirudinea 5, Hydracarina 13, Malacostraca 4, Ostracoda 6, Tricladida 4.

Some groups of the macro-zoo fauna (Gastropoda, Hirudinea, Malacostraca) also differed significantly in the two examined years along the length of the stream both regarding the composition and the expansion of the species. The explanation to this phenomenon might be the shortage of rainfalls in 2001 on the one hand, and the different contaminations affecting the stream on the other.

The members of the mezo-zoo fauna also showed relevant differences in the two examined years. While in 1999 the Tetves stream did not have its own water mite group, only the taxa driven to the outlet from the coastal regions of Lake Balaton were collectable, in 2001 a water mite stock characteristic to flatland streams established itself in the middle parts of the stream.

The taxon number of small crabs (Cladocera, Ostracoda, Copepoda) reduced from 23 , examined in earlier years, to 18 in 2001 . The difference in the number of species was especially high in spring when the 13 species found in 1999 reduced to just 4 in 2001 .

In 2001 the prevalence among small crabs changed significantly too, the dominance of Cyclops species was replaced by a partial Simocephalus (Cladocera) dominance.

The changes that took place in animal groups in Tetves streams may have more reasons: (1) the shortage of rainfalls in 2001, (2) the water quality change in the stream, (3) the effect of the 8 fish-ponds in Irmapuszta. 